\title{
Enterogastric regulation of the plasma insulin response following ingestion of a novel milk protein matrix in young and elderly women
}

\author{
W. McCormack, O. Power and P. Jakeman \\ Department of Physical Education and Sport Sciences, University of Limerick, Limerick, Republic of Ireland
}

Bovine milk is a complete food with intrinsic bioactive properties ${ }^{1}$. A glucose independent increase in the circulating concentration of the incretin hormones in response to the ingestion of milk proteins has been previously reported ${ }^{2}$. The aim of this study was to characterise the insulinotropic and enterogastric properties of a novel milk protein matrix in vivo. In addition, we sought to determine if a difference exists in the enteroinsular response with age.

With ethical approval, eight 18-29y old (YOUNG) and eight 50-70y old (OLD) women participated in the trial. Participants were randomly assigned to ingest either a novel milk protein matrix (PRO; $0.33 \mathrm{~g} . \mathrm{kg}, 10 \% \mathrm{w} / \mathrm{v}$ water) or an isocaloric maltodextrin (MALT; 0.33 g.kg, 10\% w/v water) control beverage. Serial blood samples were withdrawn prior to and post ingestion for a period of $1 \mathrm{~h}$ and batch analysed for glucose, insulin, essential amino acids (EAA), active glucagon like peptide 1 (GLP-1) and glucose dependent insulinotropic polypeptide (GIP). Data are reported as the mean (SE) area under the curve from baseline for 60 min $\left(\triangle \mathrm{AUC}_{60} ; \mathrm{n}=8\right)$.

Following ingestion of the PRO, the relative insulinotropic potency was $48 \%$ and $60 \%$ of the equivalent MALT control for YOUNG and OLD, respectively. This glucose independent insulinotropic potency of the PRO is mediated by the EAA and incretin hormones. Independent of the nutrient ingested there was an enhanced incretin response with age and though, not proven as causal, the $124 \%$ greater insulinotropic response of PRO may be related to the $208 \%$ greater GLP-1 and $165 \%$ greater GIP in OLD.

\begin{tabular}{|c|c|c|c|c|c|c|c|c|c|c|c|}
\hline \multirow[b]{3}{*}{$\Delta \mathrm{AUC}_{60}$} & \multicolumn{4}{|c|}{ MALT } & \multicolumn{4}{|l|}{ PRO } & \multirow{2}{*}{\multicolumn{3}{|c|}{ Univariate ANOVA $^{1}$}} \\
\hline & \multicolumn{2}{|c|}{ YOUNG } & \multicolumn{2}{|l|}{ OLD } & \multicolumn{2}{|c|}{ YOUNG } & \multicolumn{2}{|l|}{ OLD } & & & \\
\hline & Mean & $\overline{\mathrm{SE}}$ & Mean & $\overline{\mathrm{SE}}$ & Mean & $\overline{\mathrm{SE}}$ & Mean & $\overline{\mathrm{SE}}$ & $\overline{\text { Age }}$ & Feed & $\overline{\text { Age } * \text { Feed }}$ \\
\hline Insulin $\left(\mathrm{nM} \cdot \mathrm{h}^{-1}\right)$ & $15 \cdot 7$ & $2 \cdot 5$ & $15 \cdot 5$ & 4.5 & $7 \cdot 5$ & $2 \cdot 2$ & $9 \cdot 3$ & 1.4 & 0.783 & $0 \cdot 019^{\mathrm{b}}$ & 0.742 \\
\hline Glucose $\left(\mathrm{mM} \cdot \mathrm{h}^{-1}\right)$ & 57 & 13 & 61 & 16 & -14 & $7 \cdot 3$ & -15 & $7 \cdot 1$ & 0.902 & $<0.001^{\mathrm{a}}$ & $0 \cdot 840$ \\
\hline EAA $\left(\mathrm{mM} \cdot \mathrm{h}^{-1}\right)$ & $-3 \cdot 8$ & $0 \cdot 6$ & $-4 \cdot 3$ & 0.9 & 39 & $3 \cdot 4$ & 41 & $4 \cdot 7$ & 0.718 & $<0.001^{\mathrm{a}}$ & 0.599 \\
\hline GLP-1 (pM.h $\left.{ }^{-1}\right)$ & 30 & 18 & 69 & 32 & 36 & 12 & 75 & 15 & 0.067 & 0.772 & 0.980 \\
\hline $\operatorname{GIP}\left(\mathrm{pM} \cdot \mathrm{h}^{-1}\right)$ & 978 & 159 & 1678 & 285 & 504 & 88 & 830 & 151 & $0.011^{\mathrm{b}}$ & $0 \cdot 002^{\mathrm{b}}$ & $0 \cdot 329$ \\
\hline
\end{tabular}

EAA, essential amino acids; GLP-1, Glucagon like peptide 1; GIP, Glucose-dependent insulinotropic polypeptide. ${ }^{1}$ Univariate ANOVA (age and feed as fixed factors) ${ }^{\mathrm{a}} \mathrm{p}<0.001,{ }^{\mathrm{b}} \mathrm{p}<0.05$.

Milk protein is a rich source of pluripotent bioactive peptides. These data confirm the, glucose independent, insulinotropic and enterogastric potency of milk proteins in $v i v o^{2}$. In the elderly protein breakdown is one component of the age related decline in lean tissue mass. The PRO matrix evaluated here provides sufficient substrate for protein synthesis ${ }^{3}$. Though insulin is permissive to protein synthesis, the higher insulinotropic action of PRO in the elderly could contribute to a moderation of net protein breakdown and the conservation of lean tissue mass. The use of this PRO matrix, in this application, warrants further exploration.

Work described herein was supported by Enterprise Ireland under grant number TC20130001.

1. FitzGerald RJ, Meisel H. (2003) Advanced Dairy Chem: Proteins. 3rd ed. New York, 675-98.

2. Power O, Conway C, McCormack W et al. (2011) Proc Nut Soc 70(OCE6), E357.

3. Luiking YC, Deutz NEP, Memelink RG et al. (2014) Nutr J, 13:9. 